\title{
SOSIALISASI BROWNIES KULIT PISANG SEBAGAI PRODUK PANGAN ALTERNATIF DI DESA PIKAT-KECAMATAN DAWAN KABUPATEN KLUNGKUNG
}

\author{
T. Darmayanti ${ }^{1}$, N.L.A. Yusasrini² ${ }^{2}$ P.A.S. Wipradnyadewi ${ }^{3}$, dan A.A.G.N.A. Jambe ${ }^{4}$
}

\begin{abstract}
ABSTRAK
Desa Pikat merupakan salah satu desa yang terdapat di Kecamatan Dawan, Kabupaten Klungkung. Masyarakat Desa Pikat mayoritas memiliki mata pencaharian sebagai petani. Salah satu jenis tanaman yang banyak ditanam adalah pisang. Pisang banyak dimanfaatkan baik untuk upacara keagamaan bagi masyarakat Hindu di Bali maupun untuk dikonsumsi. Kulit pisang biasanya dibuang atau hanya digunakan sebagai pakan ternak. Pemanfaatan kulit pisang dapat dilakukan dengan mengolah kulit pisang menjadi kue brownies kukus. Pembuatan brownies kukus dari kulit pisang merupakan teknologi yang mudah dilakukan sekaligus mendukung upaya pemerintah untuk mengurangi konsumsi terigu. Kegiatan pengabdian masyarakat ini bertujuan untuk memberikan informasi, pengetahuan dan teknologi tepat guna dalam mengolah kulit pisang menjadi kue brownies kepada masyarakat di Desa Pikat. Masyarakat menyambut baik dilaksanakannya pelatihan tersebut, terutama ibu-ibu PKK Desa Pikat yang sangat antusias dan responsif dalam mengikuti pelatihan. Berdasarkan hasil evaluasi, secara umum mereka berpendapat bahwa kegiatan tersebut bermanfaat bagi masyarakat karena dapat menambah informasi dan meningkatkan pengetahuan masyarakat. Masyarakat Desa Pikat memberikan penilaian yang positif untuk produk brownies kulit pisang, baik dari segi warna, aroma, tekstur, rasa, maupun penerimaan secara keseluruhan, dengan kategori suka hingga sangat suka.
\end{abstract}

Kata kunci: Desa Pikat,kulit pisang,brownies.

\begin{abstract}
Pikat is one of the villages in Dawan sub-district, Klungkung regency. The majority of Pikat villagers have livelihoods as farmers. One type of plant which widely grown is bananas. Bananas are widely used both for religious ceremonies for the Hindu community in Bali and for consumption. Banana peels are usually discarded or used only as animal feed. Utilization of banana peel can be done by processing banana peel into steamed brownie cake. The making of banana brownies from banana peel is a technology that is easy to do while supporting government efforts to reduce wheat consumption. Community service activity aims to provide information, knowledge and appropriate technology in processing banana peel into brownie cake to the community in Pikat Village. People of Pikat village were very enthusiastic and responsive in following the training. Based on the results of evaluation in the form of distributing questionnaires, they generally argue that the activity is beneficial to the community because it can increase information and improve the knowledge of the community. The people of Pikat Village provide positive ratings for banana peel brownies, both in terms of color, aroma, texture, taste, and overall acceptance, with the likes to the very likes.
\end{abstract}

Keywords: Pikat Village, banana peel, brownies.

\footnotetext{
${ }^{1}$ PS. Ilmu dan Teknologi Pangan Universitas Udayana, Email: trisnadarmayanti@unud.ac.id.

${ }^{2}$ PS. Ilmu dan Teknologi Pangan Universitas Udayana, Email: ari_yusasrini@yahoo.com

${ }^{3}$ PS. Ilmu dan Teknologi Pangan Universitas Udayana, Email: ptarisandhiw@yahoo.com

${ }^{4}$ PS. Ilmu dan Teknologi Pangan Universitas Udayana, Email: aagn.anom.jambe@gmail.com
} 


\section{PENDAHULUAN}

Desa Pikat merupakan salah satu desa yang terdapat di Kecamatan Dawan, Kabupaten Klungkung. Masyarakat Desa Pikat mayoritas memiliki mata pencaharian sebagai petani. Lahan pertanian masyarakat banyak ditanami dengan tanaman buah (seperti kelapa dan pisang) dan tanaman pangan seperti padi, jagung, kedelai. Desa Pikat memiliki kelompok-kelompok tani dan ternak sebagai upaya untuk mendukung peningkatan hasil di bidang pertanian serta penyelamatan lingkungan (Anon, 2017a). Masyarakat di Bali yang beragama Hindu pada setiap upacara keagamaan selalu menggunakan pisang sebagai tanda persembahan kepada Tuhan, sehingga pisang selalu menjadi komoditi yang banyak digunakan baik untuk dikonsumsi maupun untuk upacara keagamaan. Beberapa jenis pisang yang digunakan saat upacara keagamaan diantaranya pisang raja, pisang susu, pisang mas, dan pisang kepok (di Bali dikenal dengan pisang saba).

Pisang yang dipergunakan di masyarakat menyisakan kulit pisang yang tidak termanfaatkan sehingga menjadi limbah. Kulit pisang biasanya dibuang begitu saja atau dikubur di dalam tanah. Sejauh ini masyarakat di Bali hanya memanfaatkan kulit pisang sebagai pakan ternak. Hal yang menarik dari kulit pisang yaitu kulit pisang ternyata dapat dikonsumsi kembali. Kulit pisang diketahui masih mengandung gizi yang baik bagi tubuh manusia. Salah satu jenis kulit pisang yang dapat dimanfaatkan kembali menjadi produk pangan adalah kulit pisang kepok. Kulit pisang mengandung air dalam jumlah besar yaitu mencapai $68,90 \%$, unsur kedua yg terkandung cukup besar dalam kulit pisang yaitu karbohidrat sebesar 18,50 \% (Anon, 2013). Menurut Dewati (2008) setiap 100 gram kulit pisang kepok mengandung air 73,60\%, protein 2,15\%, lemak 1,34\%, gula pereduksi 7,62\%, pati 11,48\%, serat kasar 1,52\%, abu 1,03\%, Vitamin C $36 \mathrm{mg} / 100 \mathrm{~g}$, Ca 31 $\mathrm{mg} / 100 \mathrm{~g}$, Fe $26 \mathrm{mg} / 100 \mathrm{~g}, \mathrm{P} 63 \mathrm{mg} / 100 \mathrm{~g}$. Kulit pisang diketahui memiliki khasiat dapat meningkatkan kadar serotonin yang berfungsi untuk mengatur kerja usus, untuk regulasi suasana hati, menjaga kesehatan mata dan melindunginya dari katarak, dapat bersifat sebagai antioksidan alami, membantu meredakan nyeri dan mempercepat penyembuhan luka (Anon, 2013). Salah satu pemanfaatan kulit pisang adalah pengolahan kulit pisang (dalam hal ini kulit pisang kepok) menjadi kue brownies kukus. Kue brownies merupakan salah satu produk pangan yang cukup dikenal dan sangat digemari di masyarakat. Secara umum brownies dibuat dari bahan-bahan seperti terigu, mentega, gula, telur, coklat yang telah dilelehkan, serta kacang almond. Pada saat ini brownies telah mengalami banyak modifikasi dengan beragam aneka rasa tambahan seperti brownies keju, brownies pisang, blueberry, strawberry, kacang-kacangan, kopi, dan masih banyak lagi variasi brownies lainnya. Proses pembuatannya tidak hanya dipanggang, namun dapat pula dengan proses pengukusan.

Pembuatan brownies kukus dari kulit pisang merupakan teknologi yang mudah dilakukan sekaligus mendukung upaya pemerintah untuk mengurangi konsumsi terigu. Pembuatan produk ini tidak membutuhkan biaya yang tinggi serta memiliki prospek untuk dikembangkan sebagai industri rumah tangga karena sangat digemari di masyarakat untuk dikonsumsi maupun untuk upacara keagamaan. Berdasarkan potensi sumber daya alam dan sumber daya manusia yang dimiliki Desa Pikat, maka pelatihan pembuatan brownies kulit pisang sangat tepat diberikan untuk meningkatkan pengetahuan dan keterampilan masyarakat di Desa Pikat, Kecamatan Dawan, Klungkung. Kegiatan pengabdian ini bertujuan yaitu: (1). Memberikan informasi, pengetahuan dan teknologi tepat guna dalam mengolah kulit pisang menjadi kue brownies kepada masyarakat di Desa Pikat, Kecamatan Dawan Klungkung, (2). Menambah keterampilan ibu-ibu PKK Desa Pikat Kecamatan Dawan Klungkung dalam mengolah bahan pangan berupa kulit pisang menjadi kue brownies, dan (3). Mendorong upaya pengembangan industri rumah tangga berupa pembuatan kue brownies berbahan kulit pisang sehingga membantu meningkatkan pendapatan ekonomi dan membuka peluang kerja baru bagi masyarakat di Desa Pikat Kecamatan Dawan, Klungkung. 
Sebagai upaya untuk mengoptimalkan pemanfaatan potensi sumber daya yang dimiliki Desa Pikat, dalam hal ini kulit pisang yang diolah menjadi produk pangan kreatif dan bernilai gizi tinggi, maka dapat dilakukan melalui kegiatan berupa penyuluhan dan pelatihan pembuatan brownies dari kulit pisang. Kegiatan ini sekaligus dapat menambah pengetahuan dan keterampilan masyarakat dalam mengolah bahan pangan serta mendorong terciptanya industri rumah tangga dan lapangan pekerjaan baru yang mampu meningkatkan pendapatan keluarga bagi masyarakat di Desa Pikat, Kecamatan Dawan, Klungkung.

\section{METODE PELAKSANAAN}

Metode pelaksanaan kegiatan ini meliputi: (1). Kegiatan penyuluhan dan diskusi dengan ibu-ibu PKK tentang teknologi pengolahan kulit pisang menjadi kue brownies, dan (2). Praktek pembuatan kue brownies kukus berbahan kulit pisang. Adapun formulasi kue brownies kulit pisang dapat dilihat pada tabel 1:

Tabel 2.1. Formulasi brownies kulit pisang

\begin{tabular}{|l|l|l|}
\hline No. & \multicolumn{1}{|c|}{ Bahan } & \multicolumn{1}{c|}{ Jumlah } \\
\hline 1 & Kulit pisang matang (disortasi dan diblender halus) & $100 \mathrm{~g}$ \\
2 & Terigu & $25 \mathrm{~g}$ \\
3 & Coklat bubuk (dicairkan) & $25 \mathrm{~g}$ \\
4 & Coklat batangan (dicairkan) & $50 \mathrm{~g}$ \\
5 & Margarin (dicairkan) & $50 \mathrm{~g}$ \\
6 & Minyak sayur & $50 \mathrm{ml}$ \\
7 & Telur & $6 \mathrm{butir}$ \\
8 & Gula pasir halus & $200 \mathrm{~g}$ \\
9 & Ovalet & 1 sendok makan \\
10 & Garam & $1 / 2$ sendok the \\
11 & Baking powder & $1 / 2$ sendok teh \\
\hline
\end{tabular}

Sumber: Anon, 2017b; yang dimodifikasi.

Adapun proses pembuatan brownies kulit pisang yaitu: gula, telur dan ovalet yang sudah ditimbang dicampur kemudian diaduk dengan mixer hingga mengembang berwarna putih. Setelah mengembang, ditambahkan tepung terigu, kulit pisang yang sudah diblender, bubuk coklat kemudian diaduk hingga rata. Selanjutnya ditambahkan coklat batangan dan mentega cair, diaduk rata. Adonan dituang ke dalam loyang yang sudah diolesi margarin dan tepung, kemudian dikukus selama 20 menit atau hingga matang, diangkat dan ditiriskan. Diagram alir proses pembuatan brownies kukus dari kulit pisang dapat dilihat pada gambar 2.1. 


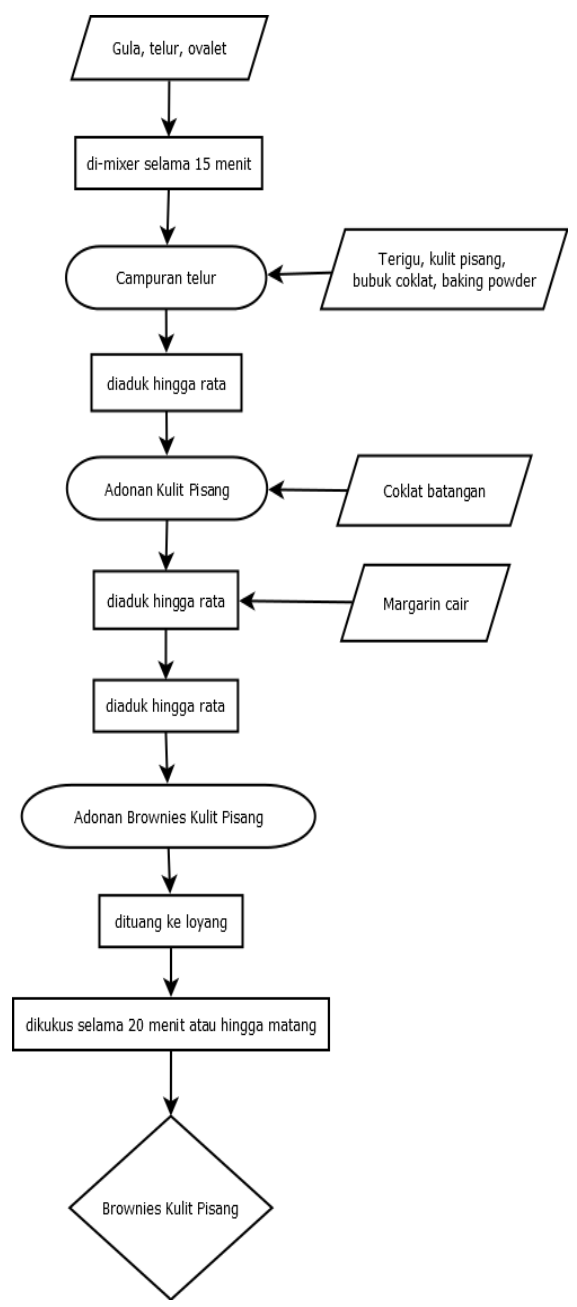

Gambar 2.1. Proses pembuatan brownies kulit pisang

\section{HASIL DAN PEMBAHASAN}

Kegiatan pengabdian kepada masyarakat di Desa Pikat, Kecamatan Dawan, Klungkung lebih diarahkan pada upaya untuk memperkenalkan hasil samping dari bahan pangan lokal yang masih memiliki nilai gizi yang cukup tinggi untuk diolah menjadi produk pangan, serta dapat menjadi alternatif dalam meningkatkan pendapatan ekonomi rumah tangga. Pelatihan pembuatan brownies dari bahan kulit pisang melibatkan ibu-ibu rumah tangga serta tim penggerak PKK di Desa Pikat. Kegiatan pengabdian ini terdiri dari tiga tahapan kegiatan yaitu tahap persiapan, tahap pelaksanaan dan tahap evaluasi yang berlangsung dari bulan Juli hingga Oktober 2017.

\subsection{Tahapan Persiapan}

Pada tahap persiapan diawali dengan kegiatan rapat dan koodinasi tim, termasuk mempersiapkan materi untuk kegiatan pelatihan. Berikutnya dilakukan survey ke lokasi dan melakukan koordinasi dengan Pengurus Tim Penggerak PKK Desa Pikat. Pada tahapan ini juga dikonfirmasi kesediaan masyarakat untuk mengikuti kegiatan sehingga dapat ditentukan jadwal yang tepat bagi pelaksanaan kegiatan pelatihan. Kegiatan yang diajukan ternyata disambut dengan antusias oleh masyarakat di Desa Pikat. 


\subsection{Pelaksanaan Kegiatan dan Partisipasi Masyarakat}

Kegiatan yang dilaksanakan pada tanggal 10 September 2017 di Balai Desa Pikat dihadiri oleh ibuibu rumah tangga PKK Desa Pikat. Kegiatan diawali dengan penyuluhan tentang manfaat dan kandungan nutrisi yang dimiliki kulit pisang. Selain itu juga dijelaskan tentang bagaimana mengolah kulit pisang sehingga menjadi produk pangan yang bernilai gizi tinggi dan layak dikonsumsi, serta kemungkinan pengembangannya menjadi industri rumah tangga yang dapat membantu meningkatkan perekonomian keluarga. Selanjutnya dilakukan pelatihan pembuatan kue brownies berbahan kulit pisang, serta sesi diskusi dan tanya jawab. Selama kegiatan berlangsung, respon ibu-ibu peserta pelatihan sangat antuasias. Ini dapat dilihat dari berbagai pertanyaan yang disampaikan saat dibuka sesi diskusi. Keingintahuan mereka terhadap produk serta bahan baku yang digunakan pada pelatihan ini menjadikan sesi diskusi sangat atraktif. Disela-sela waktu diskusi, ibu-ibu peserta pelatihan juga diajak mencicipi sekaligus memberikan penilaian terhadap produk yang sudah dibuat. Keterbatasan pengetahuan tentang manfaat dan kandungan nutrisi kulit pisang yang tergolong mudah dicari dan sangat murah, serta aplikasi pengolahan yang sederhana mendorong ibu-ibu memberikan respon yang sangat positif terhadap kegiatan tersebut, sehingga kegiatan berjalan dengan sangat baik dan lancar.

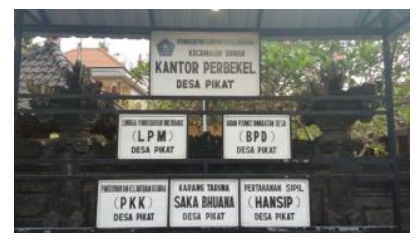

(a)

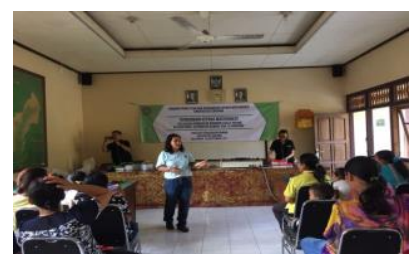

(d)

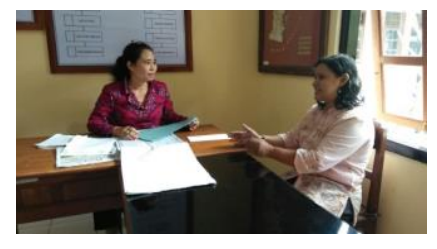

(b)

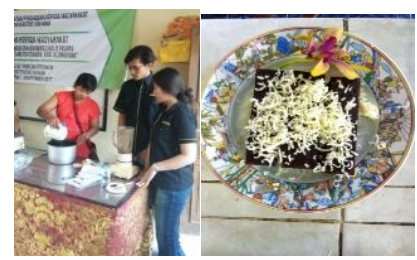

(e)

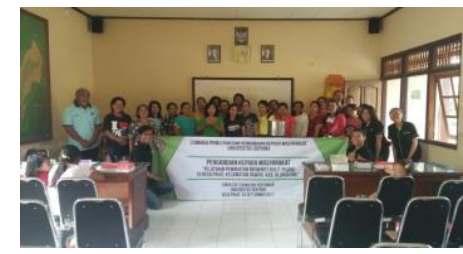

(c)

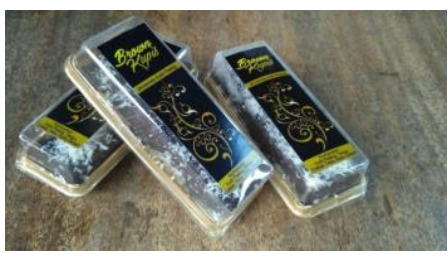

(f)

Gambar 3.1. Pelaksanaan kegiatan pengabdian: (a) Lokasi kegiatan, (b) Koordinasi dengan Tim PKK Desa Pikat, (c) Peserta pelatihan, (d) Penyampaian materi, (e) Praktek pembuatan brownies kulit pisang, (f) Produk brownies kulit pisang

\subsection{Evaluasi Kegiatan}

Evaluasi kegiatan dilakukan melalui wawancara serta penyebaran kuesioner yang berisi persepsi masyarakat terhadap produk brownies kulit pisang. Seluruh peserta (100\%) menyatakan kegiatan ini bermanfaat, karena dapat memberikan informasi baru bagi masyarakat di Desa Pikat, membantu menambah pengetahuan dan keterampilan, serta dapat menjadi peluang usaha, juga untuk menambah keragaman sarana upacara adat dan agama.

Penilaian peserta pelatihan terhadap produk brownies kulit pisang, ditinjau dari segi warna sebanyak $84 \%$ peserta menyatakan suka dan $16 \%$ menyatakan sangat suka. Ditinjau dari aromanya, sebanyak $76 \%$ peserta menyatakan suka dan $24 \%$ meyatakan sangat suka. Ditinjau dari tekstur brownies kulit pisang sebanyak $70 \%$ menyatakan suka dan 30\% menyatakan sangat suka. Brownies kulit pisang yang diproses dengan cara dikukus memiliki tekstur yang lebih lembut dibandingkan dengan brownies pada umumnya yang terbuat dari terigu. Ditinjau dari segi rasa, sebanyak $80 \%$ 
menyatakan suka dan $20 \%$ menyatakan sangat suka. Penilaian serta penerimaan terhadap produk brownies kulit pisang secara keseluruhan yaitu sebanyak 60\% menyatakan suka dan $40 \%$ menyatakan sangat suka.

Dari evaluasi kuesioner dapat dilihat penilaian yang diberikan masyarakat Desa Pikat terhadap kegiatan tersebut berada pada tingkat penilaian suka hingga sangat suka. Ini menunjukkan bahwa kegiatan pelatihan pembuatan brownies dari kulit pisang berhasil dengan sangat baik.

\section{KESIMPULAN DAN SARAN}

\subsection{Kesimpulan}

Kegiatan pengabdian kepada masyarakat berupa pelatihan pembuatan brownies dari kulit pisang dapat dinyatakan berhasil. Masyarakat di Desa Pikat, Kecamatan Dawan Klungkung, menyambut dengan baik dilaksanakannya kegiatan tersebut. Khususnya ibu-ibu PKK Desa Pikat yang sangat antusias dan responsif dalam mengikuti kegiatan pelatihan. Dari hasil evaluasi berupa penyebaran kuesioner, secara umum mereka berpendapat bahwa kegiatan tersebut bermanfaat bagi masyarakat karena dapat menambah informasi dan meningkatkan pengetahuan masyarakat. Penilaian masyarakat terhadap produk brownies kulit pisang, sebagian besar memberikan penilaian yang positif dengan kategori suka hingga sangat suka baik dari segi warna, aroma, tekstur, rasa, dan penerimaan secara keseluruhan.

\subsection{Saran}

Kegiatan serupa sangat penting untuk dilakukan secara berkesinambungan dalam bentuk pendampingan dan pembinaan bagi masyarakat desa agar dapat membantu dalam meningkatkan pengetahuan di bidang diversifikasi produk pangan yang berbasis pangan lokal serta dapat meningkatkan ketahanan pangan dan ekonomi keluarga. Untuk itu sangat diperlukan kerjasama antara instansi yang berwenang, para tokoh masyarakat, serta akademisi

\section{UCAPAN TERIMAKASIH}

Pengabdi mengucapkan terima kasih kepada Universitas Udayana, khususnya kepada Lembaga Penelitian dan Pengabdian kepada Masyarakat yang membiayai kegiatan pengabdian ini berdasarkan Surat Perjanjian Penugasan Dalam Rangka Pelaksanaan Hibah Pengabdian Kepada Masyarakat Udayana Mengabdi Tahun Anggaran 2017 Nomor: 674 - 71/UN.14.4.A/PM/2017.

\section{DAFTAR PUSTAKA}

Anonimous. 2013. Kandungan dan manfaat kulit pisang. http://tanamanobatherbal.blogspot.co.id/2013/02/kandungan-dan-manfaat-kulit-pisang.html (Diakses tanggal 20 Januari $\underline{2017) .}$.

Anonimous. 2017a. Desa Pikat Kecamatan Dawan Klungkung: Kondisi Ekonomi. http://www.pikat.desa.id/index.php/profil/97/Kondisi-Ekonomi (Diakses tanggal 20 Januari 2017)

Anonimous. 2017b. Resep Kue Brownies Kukus. Http://www.resepmasakanindonesia.me/resep-kuebrownies-kukus/. (Diakses tanggal 20 Januari 2017)

Dewati, R. 2008. Limbah Kulit Pisang Kepok Sebagai Bahan Baku Pembuatan Ethanol. Skripsi. UPN "Veteran" Jatim 